\title{
On the structural changes in the Brewer-Dobson circulation after 2000
}

\author{
H. Bönisch ${ }^{1}$, A. Engel ${ }^{1}$, Th. Birner ${ }^{2}$, P. Hoor ${ }^{3}$, D. W. Tarasick ${ }^{4}$, and E. A. Ray ${ }^{5,6}$ \\ ${ }^{1}$ Institute for Atmospheric and Environmental Sciences, Goethe University Frankfurt, Frankfurt am Main, Germany \\ ${ }^{2}$ Department of Atmospheric Science, Colorado State University, Fort Collins, CO, USA \\ ${ }^{3}$ Institute for Atmospheric Physics, University of Mainz, Germany \\ ${ }^{4}$ Environment Canada, Downsview, Ontario, Canada \\ ${ }^{5}$ Chemical Sciences Division, Earth Systems Research Laboratory, NOAA, Boulder, CO, USA \\ ${ }^{6}$ Cooperative Institute for Research in Environmental Sciences, University of Colorado, Boulder, CO, USA
}

Received: 2 November 2010 - Published in Atmos. Chem. Phys. Discuss.: 18 November 2010

Revised: 6 April 2011 - Accepted: 16 April 2011 - Published: 28 April 2011

\begin{abstract}
In this paper we present evidence that the observed increase in tropical upwelling after the year 2000 may be attributed to a change in the Brewer-Dobson circulation pattern. For this purpose, we use the concept of transit times derived from residual circulation trajectories and different in-situ measurements of ozone and nitrous dioxide. Observations from the Canadian midlatitude ozone profile record, probability density functions of in-situ $\mathrm{N}_{2} \mathrm{O}$ observations and a shift of the $\mathrm{N}_{2} \mathrm{O}-\mathrm{O}_{3}$ correlation slopes, taken together, indicate that the increased upwelling in the tropics after the year 2000 appears to have triggered an intensification of tracer transport from the tropics into the extratropics in the lower stratosphere below about $500 \mathrm{~K}$. This finding is corroborated by the fact that transit times along the shallow branch of the residual circulation into the LMS have decreased for the same time period (1993-2003). On a longer time scale (1979-2009), the transit time of the shallow residual circulation branch show a steady decrease of about $-1 \mathrm{month} / \mathrm{decade}$ over the last $30 \mathrm{yr}$, while the transit times of the deep branch remain unchanged. This highlights that changes in the upwelling across the tropical tropopause are not sufficient as an indicator for changes in the entire BrewerDobson circulation.
\end{abstract}

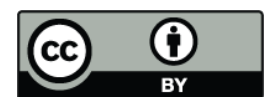

Correspondence to: $\mathrm{H}$. Bönisch (boenisch@iau.uni-frankfurt.de)

\section{Introduction}

The Upper Troposphere/Lower Stratosphere (UTLS) region represents a nexus for troposphere-stratosphere coupling as well as for chemistry-climate coupling (e.g. Shepherd, 2007). Greenhouse gases such as water vapour and ozone exhibit strong gradients across the tropopause (e.g. Pan et al., 2004). Additionally, cold tropopause temperatures cause radiative forcing to be very sensitive to the distribution of greenhouse gases in the UTLS (e.g. Forster and Shine, 1997) which impacts on climate (Solomon et al., 2010). Alongside with chemical processes, the stratospheric circulation is the main driver of trace gas distributions and thus also moderates the radiative forcing in this region. Therefore it is important to understand the stratospheric circulation and the impact of climate change on this circulation.

In recent years, there have been several model studies that indicate an intensification of the stratospheric circulation - the so-called Brewer-Dobson circulation (BDC) has already occurred (e.g. Butchart et al., 2006; Li et al., 2008). However, long-term observational data suitable for diagnostics of the BDC are very limited and sparse. Engel et al. (2009) could not confirm the model predictions of an increased BDC and corresponding decrease of mean age in the last three decades in the region of their study - the midlatitude stratosphere between $30 \mathrm{hPa}$ and $5 \mathrm{hPa}$. This apparent discrepancy between observations and models is still an open issue.

Here, the focus will be primarily on a short-term change of the stratospheric circulation. The Halogen Occultation Experiment (HALOE) satellite instrument (Russell et al., 1993)

Published by Copernicus Publications on behalf of the European Geosciences Union. 
performed near-global measurements of stratospheric water vapour since late 1991. Observations from HALOE show a substantial and persistent decrease in stratospheric water vapour beginning in approximately 2000, and continuing to about 2006. This change in water vapour was also observed in several other satellite and balloon data sets. Randel et al. (2006) attributed this drop in water vapour to the observed drop in temperatures in the tropical lower stratosphere which appear to be reasonably coincident and showed that the observed water vapour, ozone and temperature changes in the tropics after 2000 are associated with an increase in upwelling across the tropical tropopause. They also noted that the actual temperature drop at the end of 2000 appears to be correlated with an intensified Brewer-Dobson circulation. Rosenlof and Reid (2008) estimated the anomalies in the $10^{\circ} \mathrm{S}-10^{\circ} \mathrm{N}$ zonal tropical upwelling. They calculated the anomalies by first estimating the radiative heating rates using as input constituent measurements from HALOE and temperatures from UARS/UKMO, and then calculating the residual circulation streamfunction as described by Rosenlof (1995). They found a marked increase of upwelling near the tropopause level at the end of 2000 that is not evident at higher levels in the stratosphere. The cause of the increased vertical velocity in the tropics is not fully understood yet, but may be connected to a region of warmer than average tropical Pacific sea surface temperatures (Rosenlof and Reid, 2008).

A clear definition of terms is necessary when discussing possible changes in stratospheric tracer transport, especially when people have their roots in different fields of atmospheric science like chemists and dynamicists. In the discussion that follows, we will use the term Brewer-Dobson circulation (BDC) for the overall chemical tracer transport circulation of the stratosphere reflecting its discovery by Brewer (1949) and Dobson (1956) in order to explain the observed water vapour and ozone distribution in the stratosphere. The Brewer-Dobson circulation includes therefore net mass transport and two-way mixing. Only the former is related to the overall stratospheric residual circulation as represented by the Transformed Eulerian Mean (TEM) mass streamfunction. As depicted schematically in Fig. 1, the stratospheric residual circulation as part of the BDC may be considered to consist of a shallow branch transporting air within the so-called "tropically controlled transition region" (Rosenlof et al., 1997) into the extratropics and an deep branch reaching into the upper stratosphere and mesosphere (Birner and Bönisch, 2011).

Both stratospheric circulation branches are ultimately driven by Rossby waves on different scales (Plumb, 2002) with some notable contributions from gravity waves, e.g. above the subtropical jet (McFarlane, 1987; McLandress and Shepherd, 2009). According to the downward control principle (Haynes et al., 1991), the breaking of a Rossby or a gravity wave induces a meridional circulation below the level of breaking. The tropically controlled transition region is

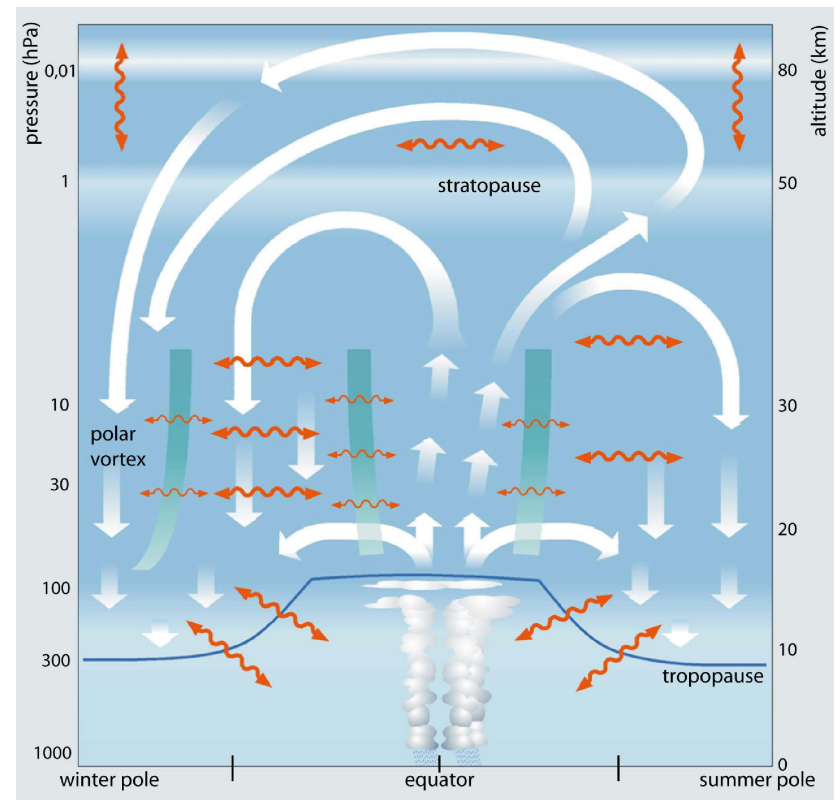

Fig. 1. Schematic of the BDC as the combined effect of residual circulation and mixing in the stratosphere and mesosphere. The thick white arrows depict the TEM mass streamfunction as representation of the residual circulation whereas the wavy orange arrows indicate two-way mixing processes. Both, circulation and mixing are mainly induced by wave activity on different scales (planetary to gravity waves). The thick green lines represent stratospheric transport and mixing barriers. The Figure is by courtesy of Dr. U. Schmidt and it is adapted from a non peer-reviewed research report of our institute.

located in the lower stratosphere (LS) between the tropical tropopause at $380 \mathrm{~K}$ and $500 \mathrm{~K}$ (up to about $20-22 \mathrm{~km}$ ). In this region, the subtropical transport barrier - marking the edge of the so-called tropical pipe (Plumb, 1996) - is rather weak (Volk et al., 1996) or "leaky" (Neu and Plumb, 1999) and quasi-horizontal mixing is intensified compared to the stratospheric levels above.

The term "tracer transport" or simply "transport" will be used here to refer to the combined processes of transport by the residual circulation in the Transformed Eulerian Mean sense (Andrews et al., 1987) and two-way mixing. The term "residual transport" will be used to describe net mass transport by the residual stratospheric circulation alone.

The purpose of this paper is to investigate transport patterns into the lower extratropical stratosphere by the use of multiple observation types, i.e. in-situ trace gas measurements and meteorological reanalysis data, in order to get a more complete picture of possible changes in the stratospheric circulation after 2000.

The paper is organized as follows: Sect. 2 discusses the data sets used, Sect. 3 describes the analysis of ozone sonde profiles (Sect. 3.1), $\mathrm{N}_{2} \mathrm{O}$ probability density functions (PDF) (Sect. 3.2) and $\mathrm{N}_{2} \mathrm{O}-\mathrm{O}_{3}$ correlations (Sect. 3.3) in the extratropical lower stratosphere in search for evidence from 
Table 1. The table shows the aircraft campaigns that provide the database for the pre- $2000 \mathrm{~N}_{2} \mathrm{O}-\mathrm{O}_{3}$ correlation used in this paper.

\begin{tabular}{lclcc}
\hline data source (aircraft) & date & reference & region $\left[{ }^{\circ} \mathrm{N}\right]$ & altitude $[\mathrm{km}]$ \\
\hline AASE II, DC-8 & $01 / 92$ & Collins et al. (1993) & 60 & $9-12$ \\
AASE II, DC-8 & $02 / 92$ & Collins et al. (1993) & 60 & $9-12$ \\
AASE II, DC-8 & $03 / 92$ & Collins et al. (1993) & 60 & $9-12$ \\
PEM_WEST(B), DC-8 & $03 / 94$ & Singh et al. (1997) & $37-57$ & $9-12$ \\
POLSTAR_1, Falcon & $01 / 97$ & Ziereis et al. (2000) & $48-80$ & $9-13$ \\
POLSTAR_2, Falcon & $02 / 98$ & Ziereis et al. (2000) & $48-80$ & $9-13$ \\
STREAM_96, Cessna & $05 / 96$ & Bujok et al. (2001) & $50-60$ & $9-13$ \\
STREAM_97, Cessna & $03 / 97$ & Hoor et al. (2002) & $65-80$ & $9-13$ \\
STREAM_98, Cessna & $07 / 98$ & Hoor et al. (2002) & $45-60$ & $9-13$ \\
\hline
\end{tabular}

measurements for a changing BDC. Section 4 shows the analysis of residual circulation trajectory calculations derived from meteorological reanalysis data set and Sect. 5 concludes.

\section{Data}

The observations in our study consist of high resolution insitu measurements of nitrous oxide $\left(\mathrm{N}_{2} \mathrm{O}\right)$ and ozone $\left(\mathrm{O}_{3}\right)$ with a focus on the extensive aircraft measurements during the STREAM (Stratosphere-Troposphere Experiments by Aircraft Measurements) and the SPURT (Spurenstofftransport in der Tropopausenregion, trace gas transport in the tropopause region) campaigns.

The STREAM project consisted of four phases covering different seasons between 1993 and 1998. Here, we only use the data obtained during the last three campaigns in spring 1996, winter 1997 and summer 1998 for reasons of data quality. These data sets have been used in many studies of the tropopause region e.g. Lelieveld et al. (1997), Bregmann et al. (1997), Fischer et al. (2000), Beuermann et al. (2002) and Hoor et al. (2002). The whole STREAM data set has been recompiled. In addition, consistent calculations of meteorological parameters along the flight tracks on the basis of ECMWF operational data as well as trajectory diagnostics have been added using the LAGRANTO trajectory scheme (Wernli and Davies, 1997). The updated meteorological data along the flight track contain consistent calculation of e.g. distance to the local tropopause (defined by the 2-PVU surface) in potential temperature units and minimum and maximum potential vorticity (PV) values along the individual back-trajectories.

The SPURT campaigns between 2001 and 2003 covering two complete seasonal cycles. A detailed description of the campaigns and the measurements is given by Engel et al. (2006). The measurements during both projects were carried out in the extratropical UTLS between $30^{\circ} \mathrm{N}$ and $80^{\circ} \mathrm{N}$ latitude and below a level of $380 \mathrm{~K}$ potential temperature.
In order to extend the pre-2000 $\mathrm{N}_{2} \mathrm{O}$ and $\mathrm{O}_{3}$ data set, we include further in-situ measurements from other aircraft campaigns, whereby we focus exclusively on the northern hemispheric lowermost stratosphere (LMS). Therefore we use extratropical in-situ measurements obtained in a similar vertical range as the post-2000 SPURT reference measurements. We chose the high quality DC-8 data sets obtained during AASE II (Airborne Arctic Stratospheric Expedition) and PEM-West(B) and the $\mathrm{N}_{2} \mathrm{O}$ and $\mathrm{O}_{3}$ measurements obtained during the POLSTAR (Polar Stratospheric Aerosol Experiment) campaigns. Table 1 shows the detailed list of the different data sets including the references.

In addition we use the balloon-borne ozonesonde data record from 1980-2010 over Canada (Tarasick et al., 2005), in particular the profiles observed at the three Canadian ozone network stations located in the midlatitudes: Goose Bay $\left(53.3^{\circ} \mathrm{N}, 60.3^{\circ} \mathrm{W}\right)$, Edmonton $\left(53.6^{\circ} \mathrm{N} .116 .1^{\circ} \mathrm{W}\right)$ and Churchill $\left(58.8^{\circ} \mathrm{N}, 94.1^{\circ} \mathrm{W}\right)$. All these measurements were made with ECC (Electrochemical Concentration Cell) sondes.

For the evaluation of possible changes in the residual stratospheric circulation we use the concept of residual circulation trajectories as described originally by Rosenlof (1995) and recently used by Birner and Bönisch (2011) to evaluate the structure of the stratospheric residual circulation. Here, the residual circulation trajectories have been calculated using the Japanese reanalysis product JRA-25 (Onogi et al., 2007) in the way as described by Birner and Bönisch (2011).

\section{Evidence from measurements}

\subsection{Midlatitude ozone profiles}

The tropical upwelling into the stratosphere, defined as the mass flux through the $100 \mathrm{hPa}$ isobar, increased after the year 2000 (Randel et al., 2006). Consequently, extratropical downwelling through this pressure surface should have increased similarly due to mass conservation. Thus, the ozone mixing ratios on pressure surfaces should have increased in 
the extratropical lower stratosphere by the intensified downwelling in the same manner as ozone has decreased in the tropics by the intensified upwelling (Randel et al., 2006).

Figure 2 shows time series of ozone mixing ratio anomalies in pressure layers from $400 \mathrm{hPa}$ to $6.3 \mathrm{hPa}(\sim 5.5 \mathrm{~km}$ to $34 \mathrm{~km}$ ) from 1980 to 2010 , as derived from balloon-borne ozone profiles observed at three northern midlatitude stations in Canada. Strong positive signals in the ozone mixing ratio anomalies in the lower midlatitude stratosphere occur after the year 2000. These are confined to the lower stratosphere up to the $100-63 \mathrm{hPa}$ level (see Fig. 2). The average for the three stations (Edmonton, Goose Bay and Churchill), 2002 shows the largest spring (MAM) anomalies in the record, for both $250-158 \mathrm{hPa}$ and $158-100 \mathrm{hPa}$, even larger than the negative anomalies in 1993 (from the Pinatubo eruption). Both levels are more than 2 standard deviations above the mean. 2003, 2004 and 2005 are also among the highest spring anomalies. The elevated post-2000 lower stratospheric ozone was sustained for about $5 \mathrm{yr}$ in this region. The three station average is, of course, only a partial mean, but the observed strong ozone anomaly in the lower stratosphere after the year 2000 should be representative for the midlatitudes on global scale because of the long effective lifetime of ozone in this region and the fact that zonal tracer transport and mixing driven by the prevailing winds in the stratospheric surf zone (McIntyre and Palmer, 1984) is on a much shorter timescale than the downwelling.

As suggested above, the elevated lower stratospheric ozone in the extratropics could be linked directly to the enhanced downwelling in this region and indirectly to the enhanced upwelling in the tropics. This assumption is corroborated by the fact that the phase as well as the altitude range of post-2000 stratospheric ozone anomalies in the northern midlatitudes matches very well with the phase and the altitude range of intensified vertical velocity in the tropical lower stratosphere causing a decrease in ozone and water vapour (Rosenlof and Reid, 2008). Rosenlof and Reid calculated an increase by $15-20 \%$ in the tropical lower stratospheric vertical velocity at the end of the year 2000 over the previous five year average in a narrow layer above the tropopause. Furthermore, they pointed out that this increase was sustained for a period of approximately 5-6 yr.

To summarise, the positive ozone anomaly in the midlatitudes is confined to the lower stratosphere. This indicates an intensified transport of ozone rich air along the shallow branch of the BDC. Enhanced downwelling of ozone-rich air from the lower midlatitude stratosphere will lead to an increase of ozone in the LMS. On the other hand, enhanced transport of ozone-poor tropical upper tropospheric or lower stratospheric air would tend to decrease ozone in the LMS. If both processes are occurring then the downwelling of ozonerich air has to overcompensate the effect of quasi-horizontal residual transport and mixing of ozone-poor air out from the tropics.

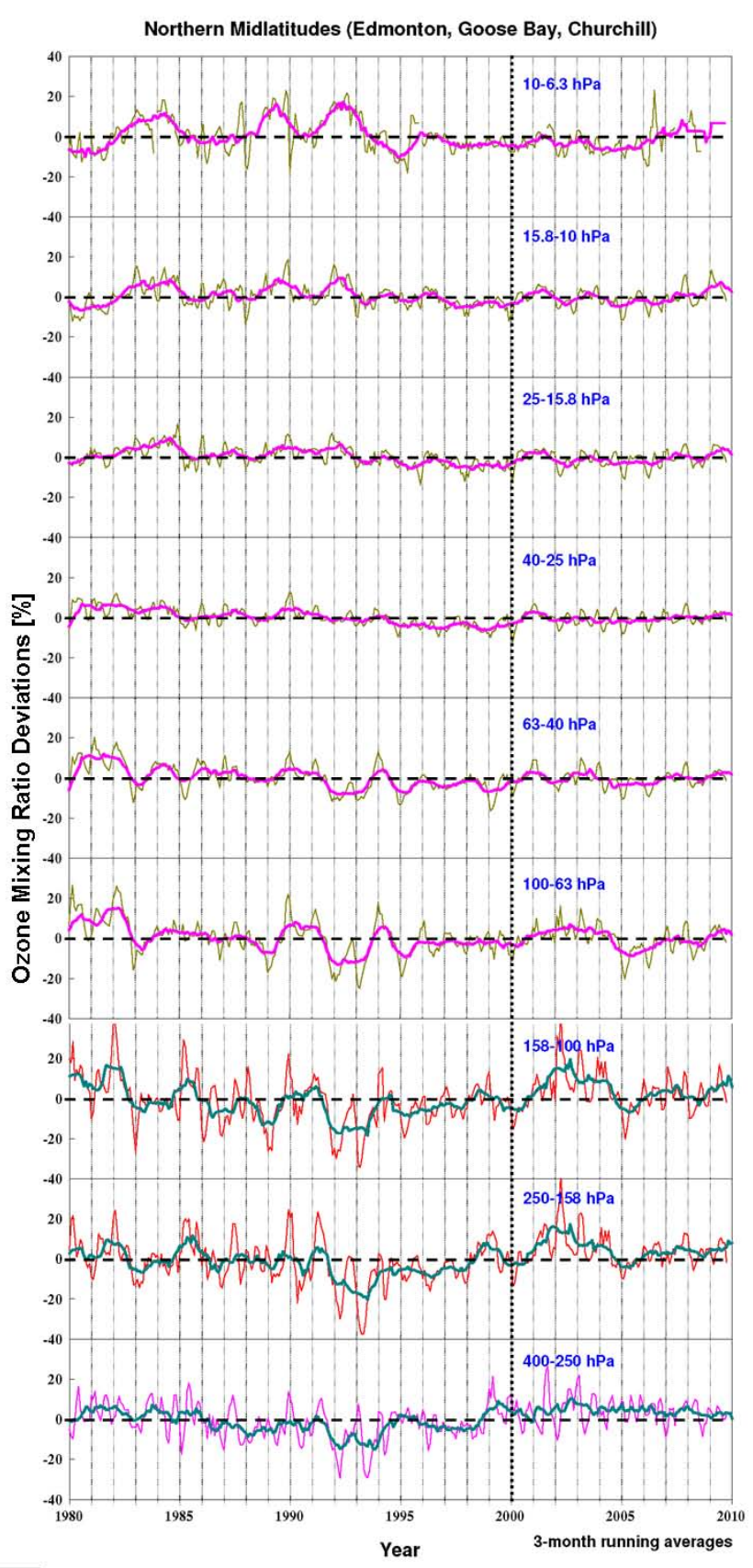

Fig. 2. Northern midlatitude time series of ozone mixing ratio deviations on different pressure levels between $400 \mathrm{hPa}$ to $6.3 \mathrm{hPa}$ derived from balloon-borne ozone profiles of the Canadian ozonesonde network. The two-coloured lines show the 3and 12-month running mean and the black dotted line indicate the year 2000. The colour code illustrates the vertical transition from the troposphere (400-250 hPa) to the lowermost stratosphere (250$100 \mathrm{hPa}$ ) to the stratospheric overworld (100-6.3 hPa). 


\subsection{Midlatitude $\mathrm{N}_{2} \mathrm{O}$-PDF}

The examination of $\mathrm{N}_{2} \mathrm{O}$ mixing ratios in the extratropical UTLS derived during the post-2000 (SPURT) and pre2000 (STREAM) measurements campaigns reveals further evidence for a change in the stratospheric trace gas distributions. Due to the strong seasonality of the $\mathrm{N}_{2} \mathrm{O}$ distribution in the LMS (e.g. Hegglin et al., 2006), it is essential to use measurements from the same month for the interannual comparison of $\mathrm{N}_{2} \mathrm{O}$ in this region. Otherwise, the characteristics of the interannual variation or trend are superimposed by the strong seasonality and therefore often become undetectable. Depending on the observed variability and the limitation of the seasonal resolution of the measurements, it is sometimes insufficient to simply use seasonal averages such as DJF or JJA.

Figure 3 shows the $\mathrm{N}_{2} \mathrm{O}$ probability distribution functions (PDF) as described by Sparling (2000) of three pre-2000 (STREAM, red lines) and three post-2000 (SPURT, blue lines) aircraft campaigns which took place during the same months of different years: February, May and July. In order to allow for direct comparisons of $\mathrm{N}_{2} \mathrm{O}$ measurements from different years, the tropospheric trend has been removed and the data set has been normalised and referenced to the year 2001. This can be seen by the congruence of the tropospheric $\mathrm{N}_{2} \mathrm{O}$ mixing ratios represented by the lowest $\mathrm{PV}$ interval $(0-$ 2 pvu). During winter and summer the $\mathrm{N}_{2} \mathrm{O}$ mixing ratios above the tropopause are higher on the same PV level for the post-2000 SPURT compared to the pre-2000 STREAM campaigns, in particular on the highest PV level (8-10 pvu). This indicates a change of the partitioning between tropospheric and stratospheric air, since the sources of $\mathrm{N}_{2} \mathrm{O}$ are entirely in the troposphere.

Air masses in the so-called free LMS (Bönisch et al., 2009) above the extratropical transition layer - the ExTL (Fischer et al., 2000) - are strongly decoupled from the local extratropical troposphere. This region is mainly influenced by quasi-horizontal transport of tropical air from the upper troposphere and lower stratosphere, as well as downwelling from the stratosphere above $380 \mathrm{~K}$ (e.g. Hoor et al., 2004). The $\mathrm{N}_{2} \mathrm{O}$ mixing ratios on the isentropes corresponding to the uppermost PV level in Fig. 3, which is definitely located in the free LMS, are higher in the tropics compared to the extratropics. The higher post-2000 $\mathrm{N}_{2} \mathrm{O}$ values in winter and summer are therefore an indication for stronger quasi-horizontal transport from the tropics into the extratropics with respect to the pre-2000 STREAM campaigns. This general picture remains unchanged when using different vertical tropopause related coordinates, e.g. distance to the local tropopause in potential temperature units, instead of PV.

At first glance, these results seem to contradict the suggestion of an intensification of the shallow branch of the BDC deduced from the midlatitude ozone profiles discussed in Sect. 3.1. To first order, enhanced downwelling in the midlatitude lower stratosphere should lead to an increase in ozone and to a decrease in the $\mathrm{N}_{2} \mathrm{O}$ mixing ratios due to the inverse source/sink pattern of both tracers in the stratosphere. However, an intensified shallow BDC branch is associated not only with enhanced extratropical downwelling but also with enhanced isentropic transport including also quasi-horizontal mixing. This implies that the influence of an intensified shallow branch of the BDC on distribution of different trace gases depends on both the relation of the vertical and the meridional (isentropic) gradients of each tracer. These specific vertical to isentropic relations $R_{\mathrm{VI}}\left(\mathrm{N}_{2} \mathrm{O}\right)$ for $\mathrm{N}_{2} \mathrm{O}$ and $R_{\mathrm{VI}}\left(\mathrm{O}_{3}\right)$ for $\mathrm{O}_{3}$ can be described by the ratios

$$
\begin{aligned}
& R_{\mathrm{VI}}\left(\mathrm{N}_{2} \mathrm{O}\right)=\frac{\left.\frac{d \mathrm{~N}_{2} \mathrm{O}(\theta)}{d \theta^{\prime}}\right|_{\text {ExTrop }}}{\left.\mathrm{N}_{2} \mathrm{O}(\theta)\right|_{\text {ExTrop }}-\left.\mathrm{N}_{2} \mathrm{O}(\theta)\right|_{\text {Trop }}} \\
& R_{\mathrm{VI}}\left(\mathrm{O}_{3}\right)=\frac{\left.\frac{d \mathrm{O}_{3}(\theta)}{d \theta^{\prime}}\right|_{\text {ExTrop }}}{\left.\mathrm{O}_{3}(\theta)\right|_{\text {ExTrop }}-\left.\mathrm{O}_{3}(\theta)\right|_{\text {Trop }}}
\end{aligned}
$$

where the numerator is the local vertical gradient at a given potential temperature $\theta$ level in the extratropics and the denominator is the difference in mixing ratio (on average) between the tropics and extratropics at a given potential temperature level.

Applying typical average values derived from in-situ $\mathrm{N}_{2} \mathrm{O}$ measurements (Proffitt et al., 2003) and satellite $\mathrm{O}_{3}$ profiles from the CATO database (Brunner et al., 2006a, b) both with potential temperature as vertical coordinate, we find that $R_{\mathrm{VI}}\left(\mathrm{O}_{3}\right)$ is about 1.5 to 3 times larger than $R_{\mathrm{VI}}\left(\mathrm{N}_{2} \mathrm{O}\right)$ in the lower stratosphere between $380 \mathrm{~K}$ and $500 \mathrm{~K}$ where the shallow BDC branch is located.

This simple qualitative estimate illustrates the different characteristics of these tracers under the influence of changing stratospheric circulation pattern. The $\mathrm{N}_{2} \mathrm{O}$ profiles in the extratropical lower stratosphere are more strongly influenced by isentropic transport and mixing of $\mathrm{N}_{2} \mathrm{O}$-rich air from the tropics while the $\mathrm{O}_{3}$ profiles are mainly determined by the strength of downwelling of $\mathrm{O}_{3}$-rich air from above. The difference in $R_{\mathrm{VI}}$ for ozone and $\mathrm{N}_{2} \mathrm{O}$ allows us to suggest that the higher $\mathrm{N}_{2} \mathrm{O}$ values in winter and summer in the post-2000 years can be explained if the effect of isentropic transport and mixing overwhelms the effect of enhanced downwelling for $\mathrm{N}_{2} \mathrm{O}$, but not for ozone. The unchanged $\mathrm{N}_{2} \mathrm{O}$-PDFs in May might be caused by the fact that the influence of downwelling on the tracer distribution of the LMS is strongest during this season (Hoor et al., 2005; Hegglin et al., 2006; Bönisch et al., 2009). Therefore, the $\mathrm{N}_{2} \mathrm{O}-\mathrm{PDF}$ is much less sensitive to changes in the isentropic transport from the tropics into the extratropics.

The interpretation of $\mathrm{N}_{2} \mathrm{O}-\mathrm{PDF}$ analysis on PV bins for the specific question of transport pathways into the LMS is not unambiguous because the tracer distributions are not sufficiently sensitive to the origin of air mass undergoing isentropic transport into the LMS. In particular, quasi-horizontal in-mixing from the tropical and subtropical troposphere 

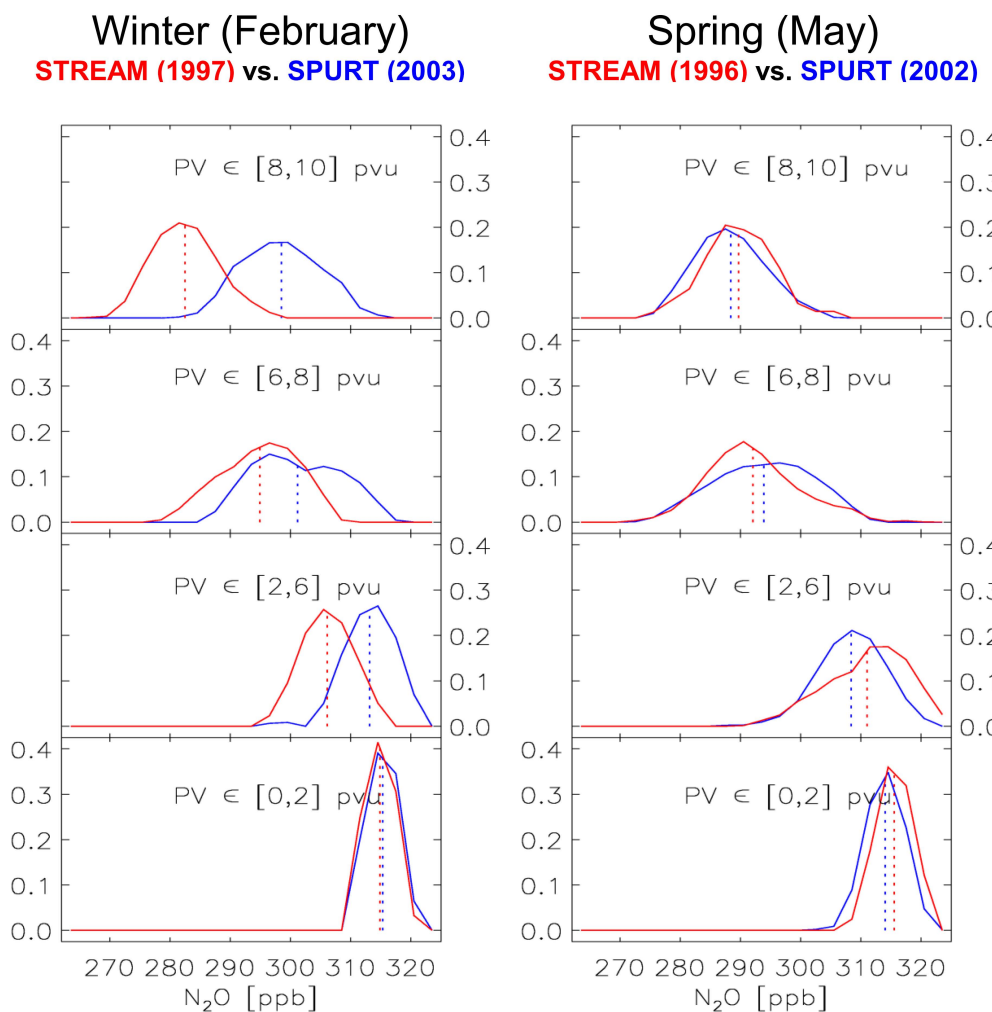

Spring (May)

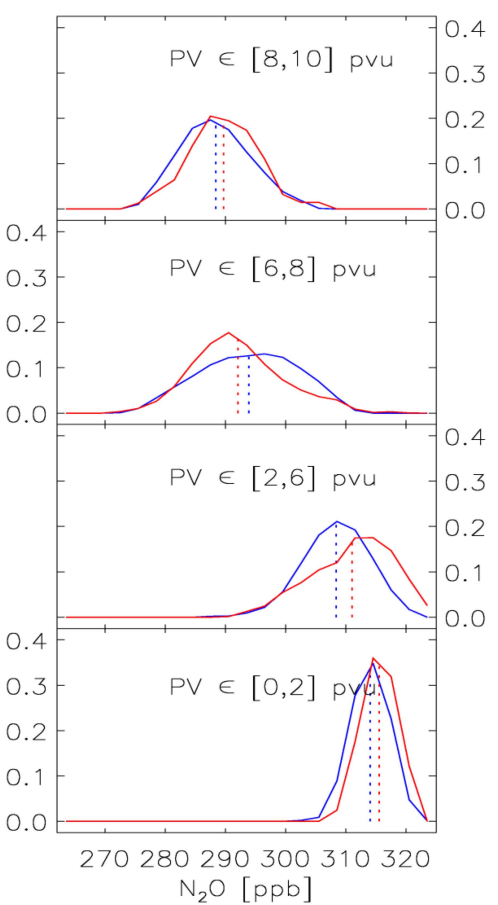

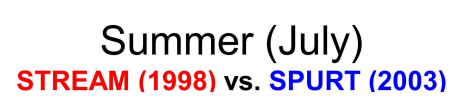

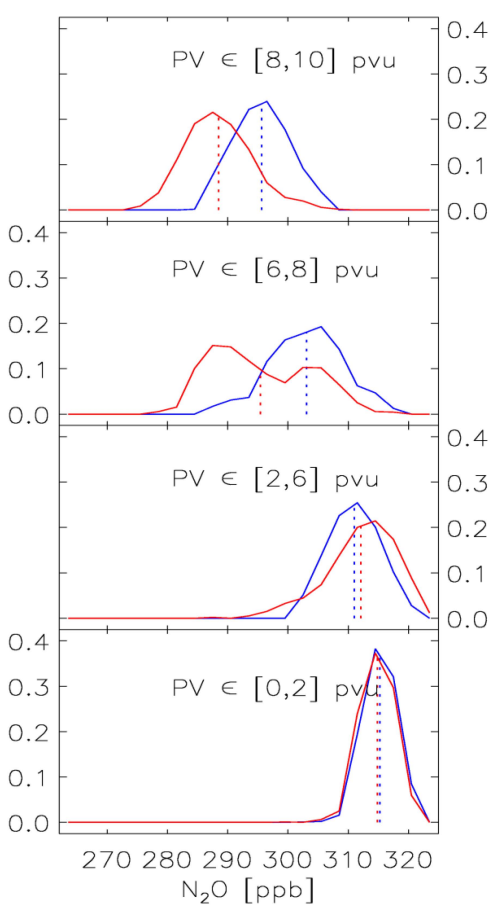

Fig. 3. $\mathrm{N}_{2} \mathrm{O}$ probability distribution function on different PV levels derived from three different pre-2000 STREAM (red) and post-2000 SPURT (blue) campaigns performed during February, May and July.

across the subtropical jet cannot be separated from residual transport along the shallow branch of the BDC into the LMS. The intensification of tracer transport along either pathway would result in higher $\mathrm{N}_{2} \mathrm{O}$ mixing ratios in the LMS as observed during the post-2000 SPURT campaigns. However, the possibility that the pre- and post- $2000 \mathrm{~N}_{2} \mathrm{O}-\mathrm{PDF}$ only differ due to intensified in-mixing of tropospheric air into the LMS is rather unlikely because this is not consistent with the enhanced ozone mixing ratios observed in the LMS post2000 (see Sect. 3.1).

\subsection{Midlatitude $\mathrm{N}_{2} \mathrm{O}-\mathrm{O}_{3}$ correlations}

Tracer-tracer correlations are a powerful diagnostic for stratospheric transport and mixing, and one which is especially valuable for the temporal and spatial sparse insitu measurements because these tracer interrelationships are much more robust than their individual distributions on different geographical and meteorological coordinates e.g. latitudes, height, isentropes or PV contours. A prerequisite for tracer correlation analysis is that the tracers have sufficiently long local lifetimes: Species whose local lifetimes are greater than vertical transport time scales are in gradient equilibrium and their mixing ratios display a linear relationship (Plumb and Ko, 1992; Plumb, 2007).

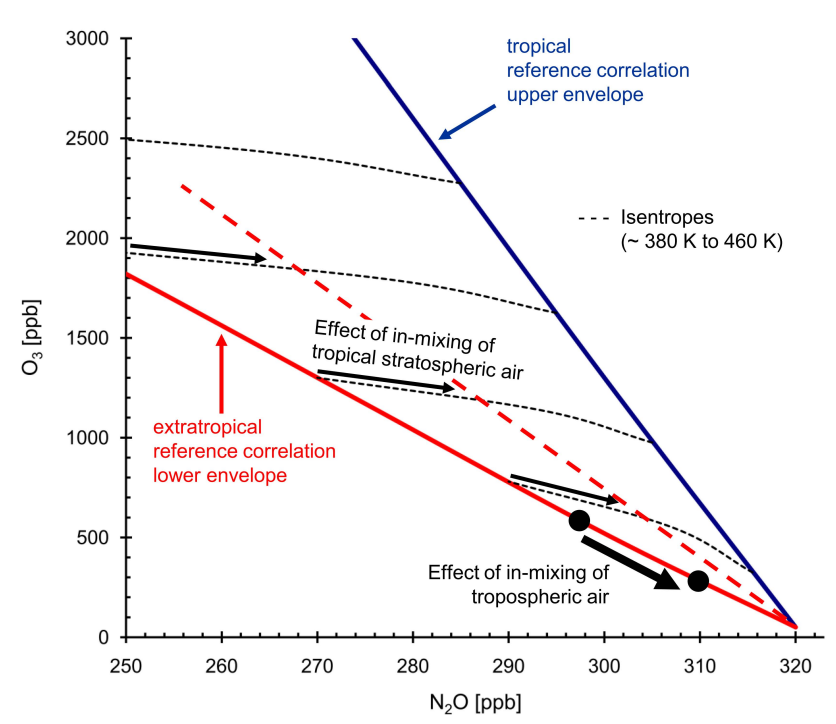

Fig. 4. Schematic of $\mathrm{N}_{2} \mathrm{O}-\mathrm{O}_{3}$ correlation in the lower stratosphere.

In particular, we are interested in the $\mathrm{N}_{2} \mathrm{O}-\mathrm{O}_{3}$ correlation in the LMS that has been also used in former studies for transport diagnostics in this region (e.g. Bregman et al., 2000; Hegglin et al., 2006; Hegglin and Shepherd, 2007). Figure 4 shows a schematic of the $\mathrm{N}_{2} \mathrm{O}-\mathrm{O}_{3}$ correlations in 
the lower stratosphere. In this region, the local effective lifetime of both tracers is greater than their vertical transport timescales so that their correlation is linear. There are two different slopes of the $\mathrm{N}_{2} \mathrm{O}-\mathrm{O}_{3}$ correlation in the lower stratosphere due to the source/sink distribution of each tracer and the existence of a transport barrier between the tropical and extratropical compartment - the edge of the tropical pipe. The slopes in the tropics and extratropics reflect an upper and a lower envelope and quasi-horizontal transport in the lower stratosphere between these regions, as indicated by the stippled lines, can change the slope of the $\mathrm{N}_{2} \mathrm{O}-\mathrm{O}_{3}$ correlation as shown by the dashed line in Fig. 4. Thus the slope of the observed $\mathrm{N}_{2} \mathrm{O}-\mathrm{O}_{3}$ correlation in the LMS is a consequence of the relative strength of vertical transport versus quasi-horizontal transport in the lower stratosphere above $380 \mathrm{~K}$ (Hegglin and Shepherd, 2007). Both processes, either increasing transport of tropical stratospheric air and/or decreasing strength of downward transport of photochemically aged air would lead to a steepening of the slope of the $\mathrm{N}_{2} \mathrm{O}$ $\mathrm{O}_{3}$ correlation in the LMS.

In contrast to the stratospheric tracer distribution on spatial and/or meteorological coordinates, the correlation of tracers like $\mathrm{N}_{2} \mathrm{O}$ and $\mathrm{O}_{3}$ will be left unchanged by mixing of tropospheric air directly across the local tropopause into the LMS since their tropospheric end-members are nearly constant (compared to the much stronger vertical gradients in the stratosphere). Therefore, the $\mathrm{N}_{2} \mathrm{O}-\mathrm{O}_{3}$ mixing ratio signature of an air parcel would only move along the existing correlation towards its end-members, as indicated in Fig. 4. In order to change the slopes of the $\mathrm{N}_{2} \mathrm{O}-\mathrm{O}_{3}$ correlation in the LMS, there must be a change in the relative strength of quasihorizontal transport in the lower stratosphere in the tropical controlled transition layer and the strength of downwelling from the overworld above.

Figure 5 shows the observed correlations between $\mathrm{N}_{2} \mathrm{O}$ and $\mathrm{O}_{3}$ mixing ratios for three different months before and after the year 2000. It is clear to see that the correlation derived from pre-2000 STREAM (red, upper panels) and post2000 SPURT (blue, lower panels) campaigns have similar seasonal variations: steeper gradients in winter and summer and flatter gradients in spring (for clarity: flatter gradients means here lower absolute values of the slope $d \mathrm{O}_{3} / d \mathrm{~N}_{2} \mathrm{O}$ ) indicating that more photochemically aged air has been subsided from the overworld into the LMS. During the $2 \mathrm{yr}$ observational phase of SPURT the most stratospheric characteristic of the LMS with the correlation closest to the extratropical lower envelope has been observed in April about 3 month after the strongest downwelling (e.g. Appenzeller et al., 1996) and the most tropospheric characteristic with the correlation closest to the tropical upper envelope has been found in October (e.g. Hoor et al., 2005; Hegglin et al., 2006; Bönisch et al., 2009). In principle, the seasonality of the $\mathrm{N}_{2} \mathrm{O}$ and $\mathrm{O}_{3}$ relationship is driven by the variation of the intensity of downward transport relative to the intensity of isentropic transport.
One can also see that the slopes of the $\mathrm{N}_{2} \mathrm{O}-\mathrm{O}_{3}$ correlation exhibit significant interannual differences for the same given month. During all three pre-2000 STREAM campaigns flatter gradients for the respective month have been observed compared to the post-2000 SPURT campaigns, indicating a larger contribution of tropospheric air after the year 2000 in the LMS. This finding corroborates the hypothesis of an intensified quasi-horizontal transport into the lower stratosphere which has also been concluded from the midlatitude ozone profiles (Sect. 3.1) and the $\mathrm{N}_{2} \mathrm{O}-\mathrm{PDF}$ analysis (Sect. 3.2).

To further this hypothesis, we add to the STREAM and SPURT data the slopes of the $\mathrm{N}_{2} \mathrm{O}-\mathrm{O}_{3}$ correlations observed during other pre-2000 aircraft measurement campaigns which took place in the LMS of the Northern Hemisphere (see Table 1). The values of the slopes $d \mathrm{O}_{3} / d \mathrm{~N}_{2} \mathrm{O}$ observed during the field campaigns AASE II, PEM-West(B) and POLSTAR have been adopted from the literature (see references in Table 1), whereas the gradients for the STREAM missions have been calculated from the reanalysed data set.

Figure 6 shows the annual variation of the slopes $d \mathrm{O}_{3} / d \mathrm{~N}_{2} \mathrm{O}$ of the observed $\mathrm{N}_{2} \mathrm{O}-\mathrm{O}_{3}$ correlations. The red curve representing the seasonality of the pre-2000 $d \mathrm{O}_{3} / d \mathrm{~N}_{2} \mathrm{O}$ gradients is evidently quite different from the post-2000 gradients depicted by the blue curve. The offset between the curves is about 6 ppb $\mathrm{O}_{3}$ perppb $\mathrm{N}_{2} \mathrm{O}$, which represents an avarage difference of about $25 \%$ between the observed slopes of the pre- and post-2000 $\mathrm{N}_{2} \mathrm{O}-\mathrm{O}_{3}$ correlations.

\section{Residual circulation trajectories}

Another approach to study stratospheric transport is the concept of residual circulation trajectories as originally described by Rosenlof (1995). More recently Birner and Bönisch (2011) have used this concept to diagnose the contribution due to the stratospheric residual circulation alone to transport into the LMS. In general, this contribution represents the advective part of the overall transport into the LMS and can be viewed as providing a background onto which the effect of mixing has to be added. For this reason, the transit time of a residual circulation trajectory from the tropopause to a specific point in the stratosphere is fundamentally different from the mean age of air (AoA) of the air parcel, because only the latter includes the effects of mixing.

Figure 7 shows the seasonal variation of the transit time of air traveling from the tropical tropopause to the LMS along the residual circulation streamfunction calculated from the JRA-25 reanalysis data set. The backward residual (timedependent) trajectories were started at a potential temperature level $30 \mathrm{~K}$ above the thermal tropopause and in the latitudinal band between $45^{\circ} \mathrm{N}$ and $60^{\circ} \mathrm{N}$. The transit times in this region just on top of the extratropical tropopause 

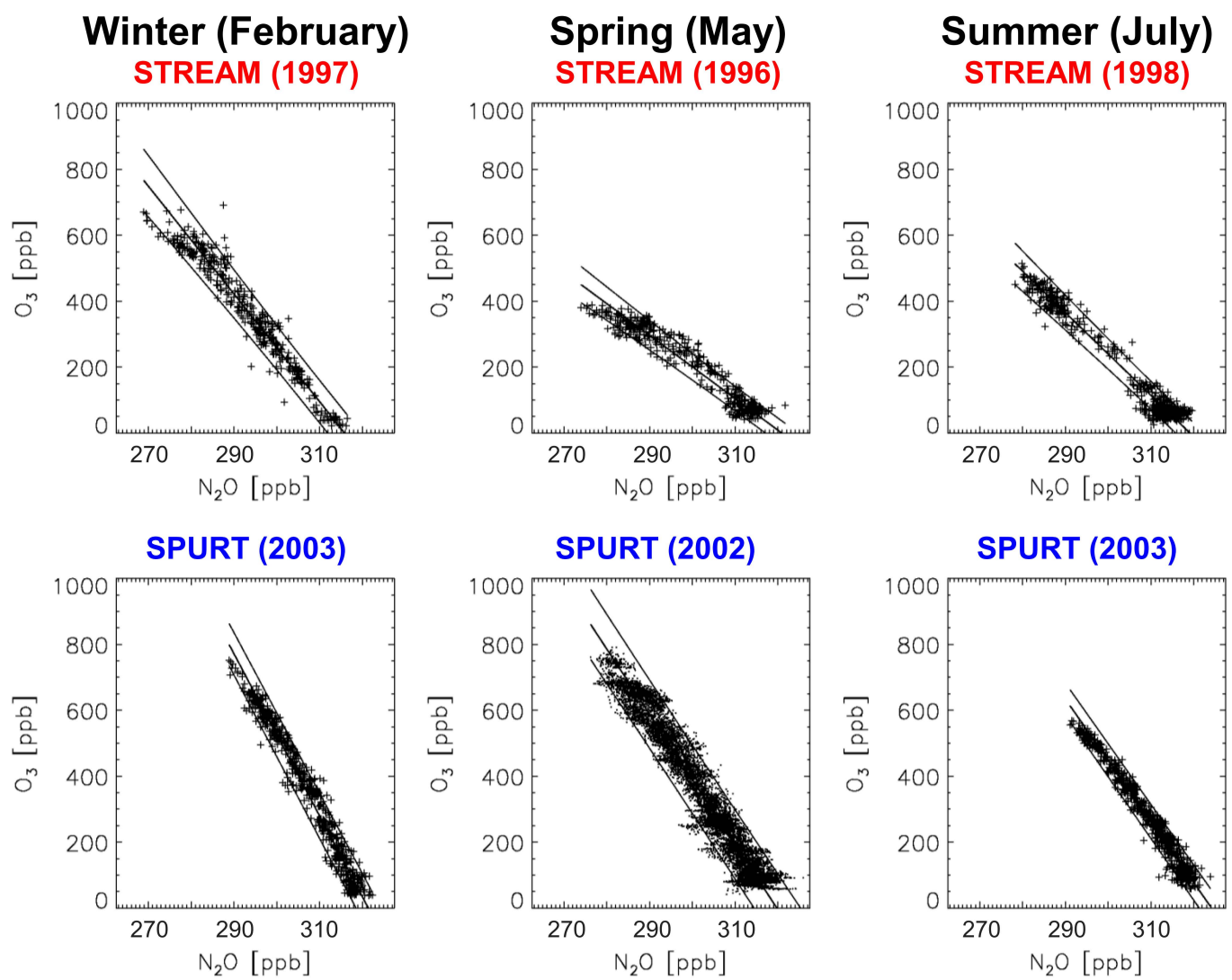

Fig. 5. $\mathrm{N}_{2} \mathrm{O}-\mathrm{O}_{3}$ correlations observed in the lowermost stratosphere during STREAM and SPURT campaigns.

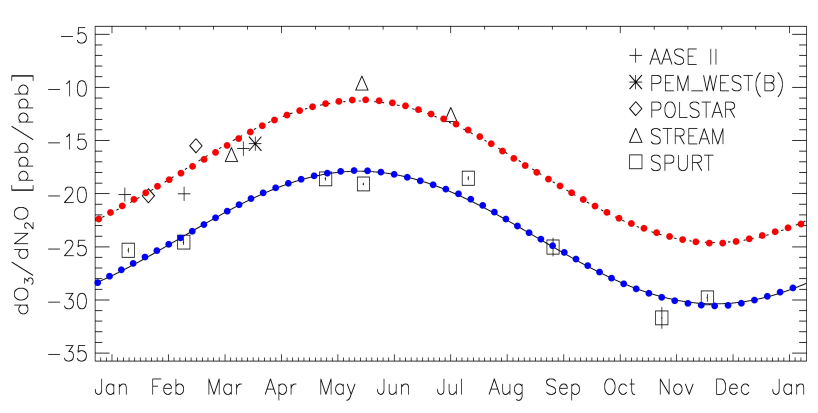

Fig. 6. Seasonality of the $d \mathrm{O}_{3} / d \mathrm{~N}_{2} \mathrm{O}$ gradients observed in the lowermost stratosphere during pre-2000 (AASE II, PEM_West(B), POLSTAR and STREAM) and post-2000 (SPURT) aircraft missions. The dotted curves represent sinusoidal fits to the pre-2000 (red) and post-2000 (blue) slopes of the $\mathrm{N}_{2} \mathrm{O}-\mathrm{O}_{3}$ correlations.

layer (ExTL) are, according to the analysis of Birner and Bönisch (2011), representative for the shallow branch of the residual circulation.

The mean seasonality of the transit times for the time periods of STREAM (1996-1998) and SPURT (2001-2003) has been calculated in order to evaluate the impact of the residual circulation on the observed tracer distribution dur- ing these aircraft campaigns. It is evident from Fig. 7 that the residual transit times are much shorter during the SPURT phase (2001-2003) compared to the STREAM phase (19961998). The shorter transit times along the shallow branch of the residual circulation are another indication that the tracer transport driven by the shallow branch of the BDC has intensified after the year 2000. Residual circulation and mixing are generally not decoupled since both mixing and the residual circulation are the result of breaking Rossby and to a lesser extent gravity waves, e.g. above the subtropical jet (e.g. McFarlane, 1987). From this point of view the residual circulation contribution should be considered a qualitative approximation to the overall transport driven by the BDC. Both seem to show the same seasonal variation. This can be seen from the similar seasonality of the $\mathrm{N}_{2} \mathrm{O}-\mathrm{O}_{3}$ correlation gradients in Fig. 6 representing tracer transport by the BDC, and that of the transit times representing the net mass transport into the LMS by the shallow residual circulation branch alone.

In contrast to the sparse high precision in-situ measurements, the JRA-25 reanalysis product also permits examination of possible changes of the residual circulation on longer timescales. As an example of the long-term behavior of the residual circulation transit times, Fig. 8 shows these annual average transit times for the period 1979-2009 from JRA-25, 


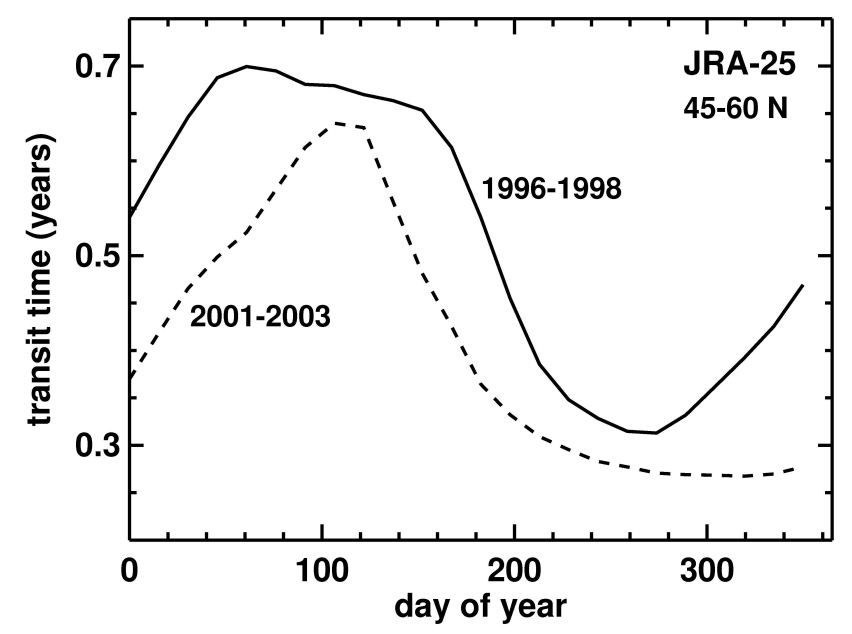

Fig. 7. Seasonality of the residual transit times at the $30 \mathrm{~K}$ level above the local thermal tropopause between $45^{\circ} \mathrm{N}$ and $60^{\circ} \mathrm{N}$ calculated from JRA-25 reanalysis data set. The solid line represents the residual transit times during the pre-2000 STREAM campaigns (1996-1998) and the dotted curves represent the post-2000 SPURT campaigns (2001-2003).

averaged between $45-60^{\circ} \mathrm{N}$ and $60-90^{\circ} \mathrm{N}$, respectively. A significant trend of about -1 month/decade exists for the midlatitudes. This trend is mainly caused by an increased velocity along the individual residual circulation trajectories $(\sim 75 \%)$ and not by the shortening of the transit pathways $(\sim 25 \%)$. Thus, these shorter transit times are indicative for an intensification of the shallow branch of the residual circulation. For the polar latitudes - representative for the deep residual circulation branch (e.g. Birner and Bönisch, 2011) - no significant trend is obtained, i.e. the deep circulation branch does not seem to undergo long-term changes in this particular data set. Although the effects of mixing are not included in this residual circulation analysis, the non-existing trend in the strength of the deep circulation branch may serve as a partial explanation for the lack of a significant trend in mean age of air estimated from in-situ observations of $\mathrm{SF}_{6}$ and $\mathrm{CO}_{2}$ (Engel et al., 2009). Most measurements used in the observational estimate were taken at altitudes and latitudes that should not be under the influence of the shallow circulation branch (indeed this possibility was noted in the paper).

In general, the stratospheric mean circulations in reanalysis data sets do not necessarily accurately represent the actual mean circulation. Thus, trends in the reanalysis circulations may not accurately represent actual trends. However, the JRA-25 is one of the best available data sets for this type of analysis and we use the trends here as an example of what may have occurred. Other reanalysis data sets will be examined in further studies focusing more on the underlying processes.

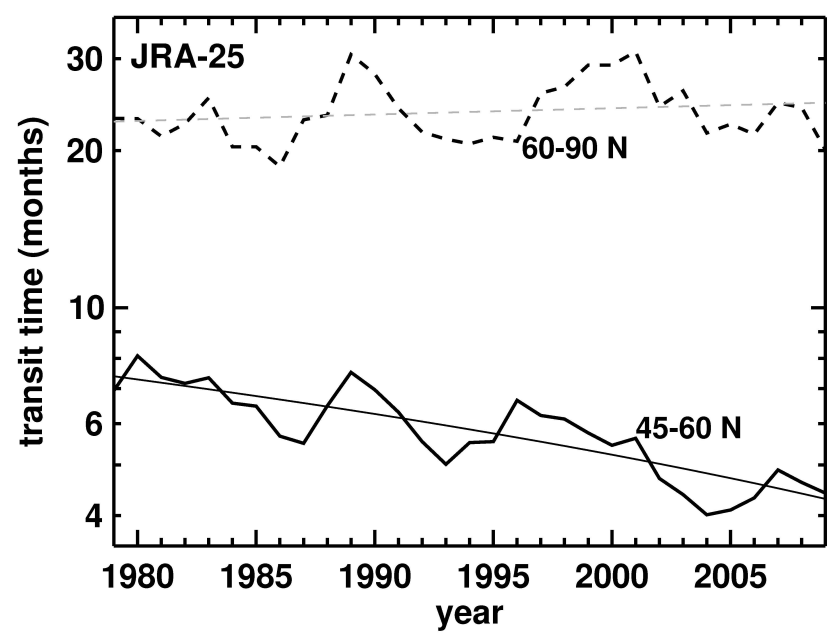

Fig. 8. Long-term trend of the residual transit times at the $30 \mathrm{~K}$ level above the local tropopause calculated from JRA-25 reanalysis data set. The solid curve represents the transit times of the shallow branch $\left(45^{\circ} \mathrm{N}-60^{\circ} \mathrm{N}\right)$ and the dashed curve represents the transit times of the deep branch of the residual circulation. The straight lines indicate the linear trend of the individual branch.

\section{Discussion and conclusion}

The starting point of this paper was that Randel et al. (2006) identified an increase in the tropical upwelling after the year 2000. Assuming that upwelling across the tropical tropopause is associated with downwelling in the extratropics through the same pressure surface, the question addressed in this paper is how the pattern of the BDC may have changed during this phase of enhanced tropical upwelling. In particular, we investigate where or at what height the coupling occurs between the enhanced upwelling in the tropics and the enhanced downwelling in the extratropics and how strong is this coupling on different isentropic levels.

Austin and $\mathrm{Li}$ (2006) showed in a model study that the two variables circulation strength, as computed from the tropical mass upwelling and age of air, are linearly related throughout the whole stratosphere. We suggest here that this is not the case for the post-2000 anomalies. According to our results the enhanced tropical upwelling is associated with an intensification of the shallow residual circulation branch alone accompanied by enhanced isentropic mixing in the same region. Both effects together form an intensified shallow branch of the BDC during the phase of the anomalies. This hypothesis will be discussed in the following.

Two results derived from the in-situ measurements imply a change in the lower stratospheric residual circulation pattern after the year 2000: (i) the increase of ozone in the extratropical lower stratosphere is indicative of intensified downwelling in the extratropics which is mainly confined to the lower stratosphere up to the $100-63 \mathrm{hPa}$ level and (ii) There is no decrease in mean age of air in the midlatitude 
stratosphere between 30-5 hPa levels until 2006 (Engel et al., 2009). Such an increase in the mass flux through the tropical tropopause would have been accompanied by a decrease in mean age of air in the extratropical stratosphere above $30 \mathrm{hPa}$, if the tracer transport occurred primarily along the deep branch of the BDC. The non-observance of a trend in mean age in the midlatitude middle stratosphere is consistent with the fact that residual circulation trajectories into the LMS calculated from the JRA-25 reanalysis do not show decreasing transit times over the last three decades in the high latitudes between $60^{\circ} \mathrm{N}$ and $90^{\circ} \mathrm{N}$. However, there is a negative trend in transit times into the LMS of about -1 month/decade in the midlatitude range between $45^{\circ} \mathrm{N}$ and $60^{\circ} \mathrm{N}$ which is representative of the shallow branch of the residual circulation.

Furthermore, the observed higher $\mathrm{N}_{2} \mathrm{O}$ mixing ratios in combination with the steeper $\mathrm{N}_{2} \mathrm{O}-\mathrm{O}_{3}$ correlation in the lowermost stratosphere indicate that the fraction of tropical air in the extratropics increased in the lower stratosphere after the year 2000. Even though the change in the tracer-tracer correlations is a very robust signal, the in-situ measurements of $\mathrm{N}_{2} \mathrm{O}$ and $\mathrm{O}_{3}$ in the LMS are ambiguous for the question whether the observed changes in the tracer distribution are driven by changes of the shallow residual circulation branch alone.

At this point, we consider whether these observed changes in the extratropical trace gas distribution in the lowermost stratosphere after the year 2000 are primarily induced by an intensified shallow residual circulation branch, or if they are also caused by intensified exchange (two-way or bidirectional transport in terms of a diffusive process) in the lower stratosphere between the two compartments: tropics and the extratropics. Ray et al. (2010) used JRA-25, NCEP and ERA-40 reanalysis data sets to show that there is a large positive trend in the mixing between tropics and extratropics in the stratosphere below $40 \mathrm{hPa}$. This is likely related to the intensified residual circulation in this region as shown by the residual circulation trajectories due to the connection between quasi-horizontal mixing and the stratospheric mean meridional circulation. The fact, that Rossby wave breaking not only drives the residual circulation below but also the quasi-horizontal mixing at the level of breaking, makes it very likely that the intensified shallow branch of the residual circulation goes hand in hand with the intensification of the shallow branch of the BDC.

Even though the individual interpretation of each of the presented diagnostics is not unambiguous, the combination of all diagnostics provides strong evidence on our hypothesis of a temporal change in the BDC pattern. This scenario of a combined intensification of the shallow residual circulation branch and quasi-horizontal mixing can explain the observed changes of $\mathrm{N}_{2} \mathrm{O}$ and ozone in the lower and lowermost stratosphere and the shorter transit times of the residual circulation trajectories started in the midlatitude LMS $\left(45^{\circ} \mathrm{N}-\right.$ $60^{\circ} \mathrm{N}$ ). The unchanged transit times in the high latitude LMS $\left(60-90^{\circ} \mathrm{N}\right)$ may only serve as a partial explanation for the observed unchanged mean age in the middle stratosphere, because an enhanced mixing in the lower stratosphere between the two compartments does not simply enhance the $\mathrm{N}_{2} \mathrm{O}$ mixing ratios in the extratropics, but would also induce at the same time a recirculation of photochemically aged air from the midlatitudes into the tropics. This would lead to an increase of the mean age of air in the tropics and subsequently also the mean age of air in the middle stratosphere of the extratropics regardless of a change in the strength of the deep residual circulation branch.

The observed 5 to $6 \mathrm{yr}$ transient change of tropical ozone and water vapour (Randel et al., 2006) after the year 2000 as well as the changes of ozone and nitrous oxide in the extratropical lower stratosphere shown here might be summarised in the statement "the Brewer-Dobson circulation has changed, but the pattern matters". This example of a temporary change in stratospheric circulation pattern and mixing illustrate how important it is to fully understand where wave drag occurs in the stratosphere and how this might change in future climate scenarios due to the possible feedback coupling mechanism of wave breaking in a changing background flow. The few studies that have addressed this issue (Garcia and Randel, 2008; McLandress and Shepherd, 2009) have come to somewhat different conclusion as to which processes are responsible for the intensified BDC in these models. The projection of future trends in stratospheric dynamics and tracer transport is critically dependent on a correct description of wave dissipation patterns on all scales from planetary to gravity waves. A prerequisite for robust projections of such changes is a thorough understanding of the past and present transport patterns and their reflection in trace gas distributions which provide strong constraints on model results.

Acknowledgements. This work was supported by the DFG research group SHARP under grant number EN 367/9-1. In particular, we would like to thank Heini Wernli, who facilitated the reanalysis of the meteorology and the back-trajectory calculations for the STREAM data set. Access to JRA25 data, originally generated by the cooperative research project of the JRA-25 long-term reanalysis by the Japan Meteorological Agency (JMA) and the Central Research Institute of Electric Power Industry (CRIEPI), was provided through NCAR.

Edited by: P. Haynes

\section{References}

Andrews, D. G., Holton, J. R., and Leovy, C. B.: Middle atmosphere dynamics, International geophysics series, v 40, Academic Press, Orlando, xi, 489 pp., 1987.

Appenzeller, C., Holton, J. R., and Rosenlof, K. H.: Seasonal variation of mass transport across the tropopause, J. Geophys. Res., 101, 15071-15078, 1996. 
Austin, J. and Li, F.: On the relationship between the strength of the Brewer-Dobson circulation and the age of stratospheric air, Geophys. Res. Lett., 33, L17807, doi:10.1029/2006g1026867, 2006.

Beuermann, R., Konopka, P., Brunner, D., Bujok, O., Gunther, G., McKenna, D. S., Lelieveld, J., Muller, R., and Schiller, C.: Highresolution measurements and simulation of stratospheric and tropospheric intrusions in the vicinity of the polar jet stream, Geophys. Res. Lett., 29, 1577, doi:10.1029/2001g1014162, 2002.

Birner, T. and Bönisch, H.: Residual circulation trajectories and transit times into the extratropical lowermost stratosphere, Atmos. Chem. Phys., 11, 817-827, doi:10.5194/acp-11-817-2011, 2011.

Bönisch, H., Engel, A., Curtius, J., Birner, Th., and Hoor, P.: Quantifying transport into the lowermost stratosphere using simultaneous in-situ measurements of SF6 and $\mathrm{CO}_{2}$, Atmos. Chem. Phys., 9, 5905-5919, doi:10.5194/acp-9-5905-2009, 2009.

Bregman, A., Arnold, F., Burger, V., Fischer, H., Lelieveld, J., Scheeren, B. A., Schneider, J., Siegmund, P. C., Strom, J., Waibel, A., and Wauben, W. M. F.: In situ trace gas and particle measurements in the summer lower stratosphere during STREAM II: Implications for $\mathrm{O}_{3}$ production, J. Atmos. Chem., 26, 275-310, 1997.

Bregman, A., Lelieveld, J., van den Broek, M. M. P., Siegmund, P. C., Fischer, $\mathrm{H}$., and Bujok, $\mathrm{O} .: \mathrm{N}_{2} \mathrm{O}$ and $\mathrm{O}_{3}$ relationship in the lowermost stratosphere: A diagnostic for mixing processes as represented by a three-dimensional chemistry-transport model, J. Geophys. Res., 105, 17279-17290, 2000.

Brewer, A. W.: Evidence for a World Circulation Provided by the Measurements of Helium and Water Vapour Distribution in the Stratosphere, Q. J. Roy. Meteorol. Soc., 75, 351-363, 1949.

Brunner, D., Staehelin, J., Kuensch, H.-R., and Bodeker, G. E.: A Kalman filter reconstruction of the vertical ozone distribution in an equivalent latitude - potential temperature framework from TOMS/GOME/SBUV total ozone observations, J. Geophys. Res., 111, 1-20, doi:10.1029/2005jd006279, 2006a.

Brunner, D., Staehelin, J., Maeder, J. A., Wohltmann, I., and Bodeker, G. E.: Variability and trends in total and vertically resolved stratospheric ozone based on the CATO ozone data set, Atmos. Chem. Phys., 6, 4985-5008, doi:10.5194/acp-6-49852006, 2006b.

Bujok, O., Tan, V., Klein, E., Nopper, R., Bauer, R., Engel, A., Gerhards, M. T., Afchine, A., McKenna, D. S., Schmidt, U., Wienhold, F. G., and Fischer, H.: GHOST - A novel airborne gas chromatograph for in situ measurements of long-lived tracers in the lower stratosphere: Method and applications, J. Atmos. Chem., 39, 37-64, 2001.

Butchart, N., Scaife, A., Bourqui, M., de Grandpré, J., Hare, S., Kettleborough, J., Langematz, U., Manzini, E., Sassi, F., Shibata, K., Shindell, D., and Sigmond, M.: Simulations of anthropogenic change in the strength of the Brewer-Dobson circulation, Clim. Dynam., 27, 727-741, doi:10.1007/s00382-006-0162-4, 2006.

Collins, J. E., Sachse, G. W., Anderson, B. E., Weinheimer, A. J., Walega, J. G., and Ridley, B. A.: AASE-II in-Situ Tracer Correlations of Methane, Nitrous-Oxide, and Ozone as Observed Aboard the DC-8, Geophys. Res. Lett., 20, 2543-2546, 1993.

Dobson, G. M. B.: Origin and Distribution of the Polyatomic Molecules in the Atmosphere, Proceedings of the Royal Society of London Series a-Mathematical and Physical Sciences, 236, 187-193, 1956.
Engel, A., Bönisch, H., Brunner, D., Fischer, H., Franke, H., Günther, G., Gurk, C., Hegglin, M., Hoor, P., Königstedt, R., Krebsbach, M., Maser, R., Parchatka, U., Peter, T., Schell, D., Schiller, C., Schmidt, U., Spelten, N., Szabo, T., Weers, U., Wernli, H., Wetter, T., and Wirth, V.: Highly resolved observations of trace gases in the lowermost stratosphere and upper troposphere from the Spurt project: an overview, Atmos. Chem. Phys., 6, 283-301, doi:10.5194/acp-6-283-2006, 2006.

Engel, A., Mobius, T., Bönisch, H., Schmidt, U., Heinz, R., Levin, I., Atlas, E., Aoki, S., Nakazawa, T., Sugawara, S., Moore, F., Hurst, D., Elkins, J., Schauffler, S., Andrews, A., and Boering, K.: Age of stratospheric air unchanged within uncertainties over the past 30 years, Nature Geoscience, 2, 28-31, doi:10.1038/Ngeo388, 2009.

Fischer, H., Wienhold, F. G., Hoor, P., Bujok, O., Schiller, C., Siegmund, P., Ambaum, M., Scheeren, H. A., and Lelieveld, J.: Tracer correlations in the northern high latitude lowermost stratosphere: Influence of cross-tropopause mass exchange, Geophys. Res. Lett., 27, 97-100, 2000.

Forster, P. M. D. and Shine, K. P.: Radiative forcing and temperature trends from stratospheric ozone changes, J. Geophys. Res., 102, 10841-10855, 1997.

Garcia, R. R. and Randel, W. J.: Acceleration of the Brewer-Dobson circulation due to increases in greenhouse gases, J. Atmos. Sci., 65, 2731-2739, doi:10.1175/2008jas2712.1, 2008.

Haynes, P. H., McIntyre, M. E., Shepherd, T. G., Marks, C. J., and Shine, K. P.: On the "Downward Control" of Extratropical Diabatic Circulations by Eddy-Induced Mean Zonal Forces, J. Atmos. Sci., 48, 651-678, 1991.

Hegglin, M. I. and Shepherd, T. G.: $\mathrm{O}_{3}-\mathrm{N}_{2} \mathrm{O}$ correlations from the Atmospheric Chemistry Experiment: Revisiting a diagnostic of transport and chemistry in the stratosphere, J. Geophys. Res., 112, D19301, doi:10.1029/2006jd008281, 2007.

Hegglin, M. I., Brunner, D., Peter, T., Hoor, P., Fischer, H., Staehelin, J., Krebsbach, M., Schiller, C., Parchatka, U., and Weers, $\mathrm{U}$.: Measurements of $\mathrm{NO}, \mathrm{NO}_{\mathrm{y}}, \mathrm{N}_{2} \mathrm{O}$, and $\mathrm{O}_{3}$ during SPURT: implications for transport and chemistry in the lowermost stratosphere, Atmos. Chem. Phys., 6, 1331-1350, doi:10.5194/acp-61331-2006, 2006.

Hoor, P., Fischer, H., Lange, L., Lelieveld, J., and Brunner, D.: Seasonal variations of a mixing layer in the lowermost stratosphere as identified by the CO-O3 correlation from in situ measurements, J. Geophys. Res., 107, 4044, doi:10.1029/2000jd000289, 2002.

Hoor, P., Gurk, C., Brunner, D., Hegglin, M. I., Wernli, H., and Fischer, H.: Seasonality and extent of extratropical TST derived from in-situ CO measurements during SPURT, Atmos. Chem. Phys., 4, 1427-1442, doi:10.5194/acp-4-1427-2004, 2004.

Hoor, P., Fischer, H., and Lelieveld, J.: Tropical and extratropical tropospheric air in the lowermost stratosphere over Europe: A CO-based budget, Geophys. Res. Lett., 32, L07802, doi:10.1029/2004g1022018, 2005.

Lelieveld, J., Bregman, B., Arnold, F., Burger, V., Crutzen, P. J., Fischer, H., Waibel, A., Siegmund, P., and van Velthoven, P. F. J.: Chemical perturbation of the lowermost stratosphere through exchange with the troposphere, Geophys. Res. Lett., 24, 603606, 1997.

Li, F., Austin, J., and Wilson, J.: The Strength of the Brewer-Dobson Circulation in a Changing Climate: Coupled 
Chemistry-Climate Model Simulations, J. Climate, 21, 40-57, doi:10.1175/2007JCLI1663.1, 2008.

McFarlane, N. A.: The Effect of Orographically Excited GravityWave Drag on the General-Circulation of the Lower Stratosphere and Troposphere, J. Atmos. Sci., 44, 1775-1800, 1987.

McIntyre, M. E. and Palmer, T. N.: The "surf zone" in the stratosphere, J. Atmos. Terr. Phys., 46, 825-849, 1984.

McLandress, C. and Shepherd, T. G.: Simulated Anthropogenic Changes in the Brewer-Dobson Circulation, Including Its Extension to High Latitudes, J. Climate, 22, 1516-1540, doi:10.1175/2008JCLI2679.1, 2009.

Neu, J. L. and Plumb, R. A.: Age of air in a "leaky pipe" model of stratospheric transport, J. Geophys. Res., 104, 19243-19255, 1999.

Onogi, K., Tsutsui, J., Koide, H., Sakamoto, M., Kobayashi, S., Hatsushika, H., Matsumoto, T., Yamazaki, N., Kamahori, H., Takahashi, K., Kadokura, S., Wada, K., Kato, K., Oyama, R., Ose, T., Mannoji, N., and Taira, R.: The JRA-25 Reanalysis, J. Meteorol. Soc. Japan, 85, 369-432, 2007.

Pan, L. L., Randel, W. J., Gary, B. L., Mahoney, M. J., and Hintsa, E. J.: Definitions and sharpness of the extratropical tropopause: A trace gas perspective, J. Geophys. Res., 109, D23103, doi:10.1029/2004jd004982, 2004.

Plumb, R. A.: A "tropical pipe" model of stratospheric transport, J. Geophys. Res., 101, 3957-3972, 1996.

Plumb, R. A.: Stratospheric Transport, J. Meteorol. Soc. Japan, 80, 793-809, 2002.

Plumb, R. A.: Tracer interrelationships in the stratosphere, Rev. Geophys., 45, RG4005, doi:10.1029/2005rg000179, 2007.

Plumb, R. A. and Ko, M. K. W.: Interrelationships between Mixing Ratios of Long Lived Stratospheric Constituents, J. Geophys. Res., 97, 10145-10156, 1992.

Proffitt, M. H., Aikin, K., Tuck, A. F., Margitan, J. J., Webster, C. R., Toon, G. C., and Elkins, J. W.: Seasonally averaged ozone and nitrous oxide in the Northern Hemisphere lower stratosphere, J. Geophys. Res., 108, 4110, doi:10.1029/2002jd002657, 2003.

Randel, W. J., Wu, F., Vomel, H., Nedoluha, G. E., and Forster, P.: Decreases in stratospheric water vapor after 2001: Links to changes in the tropical tropopause and the Brewer-Dobson circulation, J. Geophys. Res., 111, D12312, doi:10.1029/2005jd006744, 2006.

Ray, E. A., Moore, F. L., Rosenlof, K. H., Davis, S. M., Boenisch, H., Morgenstern, O., Smale, D., Rozanov, E., Hegglin, M., Pitari, G., Mancini, E., Braesicke, P., Butchart, N., Hardiman, S., Li, F., Shibata, K., and Plummer, D. A.: Evidence for changes in stratospheric transport and mixing over the past three decades based on multiple data sets and tropical leaky pipe analysis, J. Geophys. Res., 115, D21304, doi:10.1029/2010jd014206, 2010.
Rosenlof, K. H.: Seasonal Cycle of the Residual Mean Meridional Circulation in the Stratosphere, J. Geophys. Res., 100, 51735191, 1995.

Rosenlof, K. H. and Reid, G. C.: Trends in the temperature and water vapor content of the tropical lower stratosphere: Sea surface connection, J. Geophys. Res., 113, D06107, doi:10.1029/2007jd009109, 2008.

Rosenlof, K. H., Tuck, A. F., Kelly, K. K., Russell, J. M., and McCormick, M. P.: Hemispheric asymmetries in water vapor and inferences about transport in the lower stratosphere, J. Geophys. Res., 102, 13213-13234, 1997.

Russell, J. M., Gordley, L. L., Park, J. H., Drayson, S. R., Hesketh, W. D., Cicerone, R. J., Tuck, A. F., Frederick, J. E., Harries, J. E., and Crutzen, P. J.: The Halogen Occultation Experiment, J. Geophys. Res., 98, 10777-10797, 1993.

Shepherd, T. G.: Transport in the middle atmosphere, J. Meteorol. Soc. Japan, 85B, 165-191, 2007.

Singh, H. B., Chen, Y., Gregory, G. L., Sachse, G. W., Talbot, R., Blake, D. R., Kondo, Y., Bradshaw, J. D., Heikes, B., and Thornton, D.: Trace chemical measurements from the northern midlatitude lowermost stratosphere in early spring: Distributions, correlations, and fate, Geophys. Res. Lett., 24, 127-130, 1997.

Solomon, S., Rosenlof, K. H., Portmann, R. W., Daniel, J. S., Davis, S. M., Sanford, T. J., and Plattner, G. K.: Contributions of Stratospheric Water Vapor to Decadal Changes in the Rate of Global Warming, Science, 327, 1219-1223, doi:10.1126/science.1182488, 2010.

Sparling, L. C.: Statistical perspectives on stratospheric transport, Rev. Geophys., 38, 417-436, doi:10.1029/1999rg000070, 2000.

Tarasick, D. W., Fioletov, V. E., Wardle, D. I., Kerr, J. B., and Davies, J.: Changes in the vertical distribution of ozone over Canada from ozonesondes: 1980-2001, J. Geophys. Res., 110, 1-19, doi:10.1029/2004jd004643, 2005.

Volk, C. M., Elkins, J. W., Fahey, D. W., Salawitch, R. J., Dutton, G. S., Gilligan, J. M., Proffitt, M. H., Loewenstein, M., Podolske, J. R., Minschwaner, K., Margitan, J. J., and Chan, K. R.: Quantifying transport between the tropical and mid-latitude lower stratosphere, Science, 272, 1763-1768, 1996.

Wernli, H. and Davies, H. C.: A Lagrangian-based analysis of extratropical cyclones .1. The method and some applications, Q. J. Roy. Meteorol. Soc., 123, 467-489, 1997.

Ziereis, H., Schlager, H., Fischer, H., Feigl, C., Hoor, P., Marquardt, R., and Wagner, V.: Aircraft measurements of tracer correlations in the Arctic subvorter region during the Polar Stratospheric Aerosol Experiment (POLSTAR), J. Geophys. Res., 105, 2430524313, 2000. 